\title{
Comparing Drivers Cultural Sensitivity Value between Gojek and Goviet from Digital Ads
}

\author{
Natasia Angreani ${ }^{a, 1, *}$, Samantha Tandranegara ${ }^{\mathrm{b}, 2}$, Rustono Farady Marta ${ }^{\mathrm{c}, 3}$, Changsong Wang, \\ a,b,c Universitas Bunda Mulia, ${ }^{d}$ Xiamen University of Malaysia

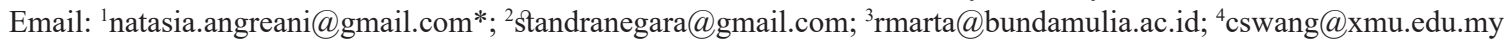 \\ *corresponding author
}

Keywords:

Intercultral Sensibility

Content Analysis

Developmental Model of

Intercultural Sensitivity

Video

\begin{abstract}
Gojek is one of the multi-service technology platform co-founded by native Indonesian. On their eight year, Gojek expand their service to other markets in Vietnam. Although Indonesia and Vietnam both located in the Southeast Asian region and have the same climate with the majority of the citizens who work as farmers and fishermen, Indonesia and Vietnam certainly have a series of differences such as language, culture, and religion. This study aims to explore the intercultural sensitivity of Gojek drivers who went to Vietnam to meet fellow Goviet drivers. Together, they enjoy the beauty of the country and experiencing Vietnamese culture which is shown in the GOINTERNATIONAL YouTube video. This study was conducted by using Bannett's theory of Developmental Model of Intercultural Sensitivity (DMIS) by the contenty analysis method in order to analyze the intercultural sensibility value on the Gojek "GO-INTERNATIONAL" video. There results indicate four stages such as minimization, acceptance, adaptation, and integration. This ads shows the existence of bonds found in different cultural backgrounds and the ethnorelativism of Gojek drivers towards Goviet drivers.
\end{abstract}

This is an open access article under the CC-BY-SA license.

Copyright (C) 2021 Channel Jurnal Komunikasi. All right reserved.

\section{INTRODUCTION}

We were looking at the advances and progressiveness of modernization. It is effortless to find various technologies or innovations in numerous countries to ease human life (Dağhan, 2017). Indonesia is also one of the countries that continues to move forward in creating technology innovation. It can be seen from the rapid growth of e-commerce and software applications built to make our lives better. The use of technology applications is now considered normal and has had a considerable impact on human life (Heryani, 2020).

The most used mobile applications by the Indonesians are the technology founded by PT Aplikasi Karya Anak Bangsa or popularly known as Gojek. Gojek is a technology-based company with a social mission to develop the lives of its workers in various informal fields in Indonesia (Kartika, 2020). Gojek was founded by a native Indonesian, Nadiem Makarim, in August 2010. Since then, this mobile application has progressively created more innovations to improve their business (Junita, 2019). The GO-JEK application has had positive impacts on the lives of Indonesian people by creating jobs opportunities with a guarantee to improve the quality of life of its workers (Rahmadani \& Fahrudin, 2020). Quoted from Gojek's official website, it was stated that Gojek drivers experience an increase in their income, and they can reach many customers through this modern application. Gojek also gave their drivers health and accident insurance. The company has collaborated with the insurance company Allianz to ensure the safety and welfare of its drivers (Allianz x GoJek, n.d.) 


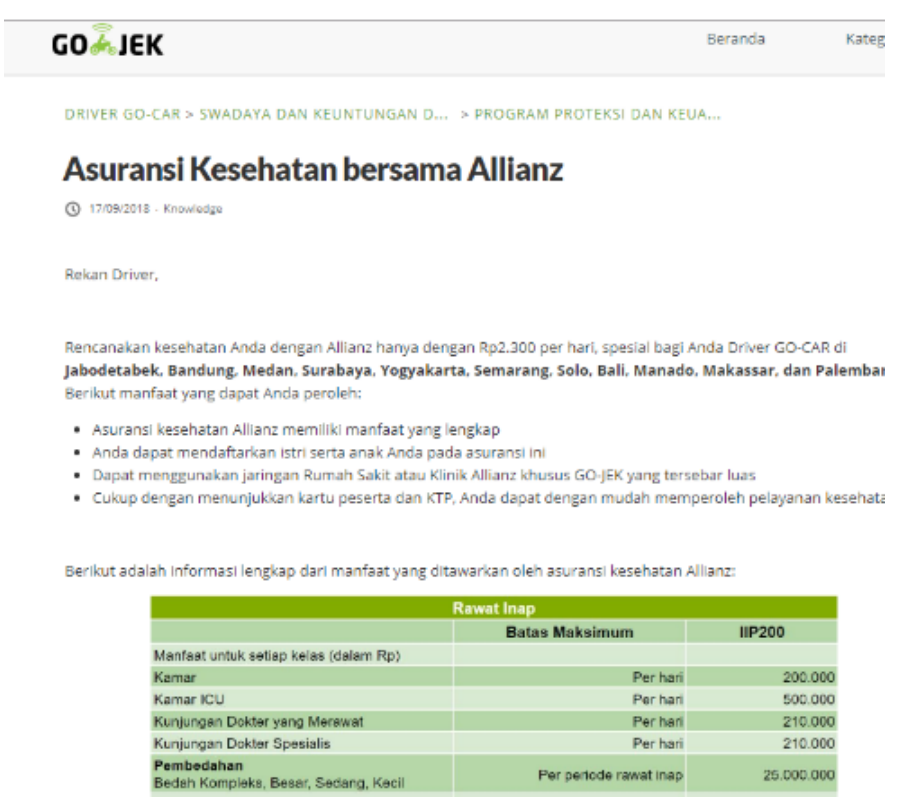

Fig 1. Allianz Insurance for Gojek Drivers

Becoming one of the top online transportation applications in Indonesia, Gojek continues its journey by making more innovations and bringing its ride-hailing-based online transportation to other countries or, in other words, by expanding its business overseas. The steps taken were also a creative way to promote Indonesia's technology start-up worldwide (Prananda et al., 2020). Setting their foot in an era where globalization makes the pace of global trade or business broader and faster, it is normal for Gojek to spread their wings and develop to the international level. Especially after the issuance of policies on employment, where foreign workers can freely enter Indonesia, and vice versa (Islam et al., 2017).

The country chosen by Gojek is Vietnam, a country also located in the Southeast Asia region. Vietnam is a country with a high population. In 2015, according to the official website of the Indonesian Ministry of Foreign Affairs for Vietnam, there were 94,348,835 million citizens. Since May 1993, the Indonesia Government has opened its Consulate in Ho Chi Minh City, one of the cities in Vietnam, which is also famous for the presence of many Indonesian people in the city. Indonesian has also become the second language in Ho Chi Minh City (Aprilyansyah, 2018).

In June 2013, the President of the Republic of Indonesia and the President of Vietnam agreed to improve bilateral relations between the two countries from comprehensive cooperation to a strategic partnership so that the door is increasingly open for the two countries to work together, and this is one of the reasons why Gojek can expand its wings at Vietnam, especially in Ho Chi Minh City. Moreover, Ho Chi Minh City is also famous for its high number of two-wheeled vehicle users (Setiadi, 2016)

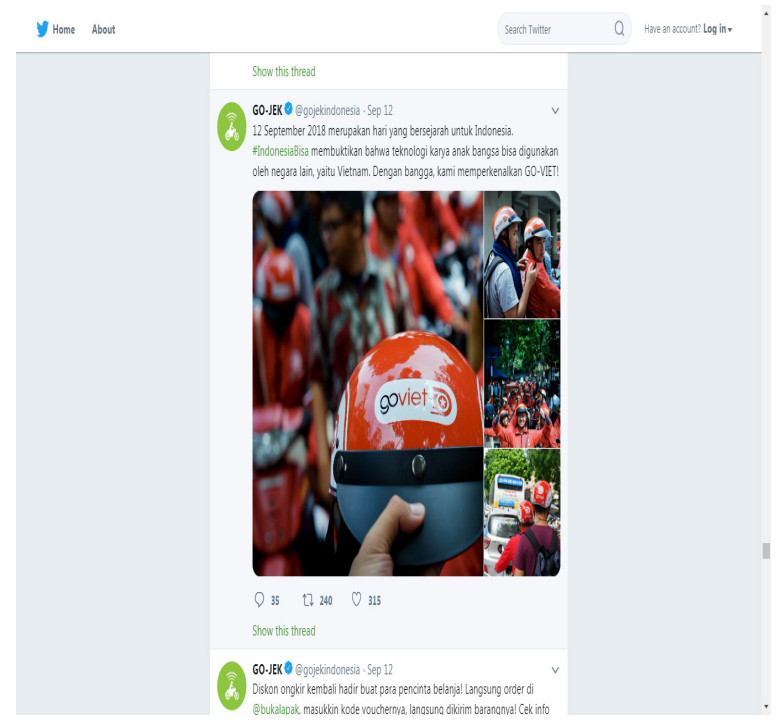

Fig 2 Gojek Tweets Regarding Their New Brand Goviet 
Goviet was the rebranding product of Gojek in Vietnam. In order to promote their new product, Gojek applied various marketing strategies, one of them being by advertising through YouTube videos (Sasongko \& Marta, 2018). Advertisement is one of the tools used by Gojek to reach its public and embed the value of its product in the public's mind. Nowadays, advertisement is not merely used to persuade or deliver messages to the public (Marta, R.F., Robin, 2019). The development of the internet made a significant impact on advertisements. In order to deliver creative audiovisual advertisements requires an effective medium. This media not only displays products but also displays the cultural values that Gojek wants to convey (R. Marta \& Rieuwpassa, 2018)

Advertisements can be spread through various media. Today, current global people have an all-digital lifestyle, where the internet has become a part of people's lives. For this reason, videos produced by Gojek are distributed through the internet (Marta, R.F., Fernando, J., 2020). Especially at this time, generation Z is very active in using technology communication devices. They are more comfortable communicating virtually rather than physically face to face communication (Sari \& Suprihatin, 2020). The advantage of using this digitalized media is its interactivity and multimedia characteristics (Setiawan et al., 2021). Other than that, the development of digital media also makes the internet a place to maximize the use of visual and audio images that would effectively help communicators convey their messages so that they can be conveyed effectively to their targets (Aziz, 2019).

The message conveyed in the Gojek advertisement are not only aimed to introduce Goviet, but the five-minute advertisement also portrayed the changes in the life of Gojek drivers after joining Gojek and how proud they are to be part of this Indonesian application made by the nation's children who have now extended their business to the international realm. Gojek's "GO INTERNATIONAL" ads also describe the joyous feelings of Gojek drivers who finally met their Soviet partners in Vietnam. The drivers are invited to tour around Ho Chi Min City to enjoy cultural and religious tourism. Vietnam and Indonesia are two countries that are both located in the Southeast Asian region. Although they belong to the same Indochina and Melayu ancestry, the two countries have differences, differing from the culture, language, and religion of the majority of the people of the two countries.

Cultural differences can cause various reactions depending on the psychology and the cultural sensibility of each individual. Gojek ads "GO INTERNATIONAL" clearly picture the reactions and feelings of the drivers when interacting with drivers from other countries. Gojek drivers seem happy and close with Goviet drivers. The Gojek driver even said that although they both do not understand the language and have different religions, they are all united as a family. They were reflecting on the visible differences. This study explores the level of intercultural sensitivity of Gojek drivers towards Goviet drivers through Gojek's "GO INTERNATIONAL” advertisement.

\section{THE PROPOSED THEORY}

In order to further examine cross-cultural sensitivity in Gojek's "GO INTERNATIONAL" advertisement, the video will be analyzed through the Bannet Developmental Model of Intercultural Sensitivity (DMIS). The Bannnet emphasized that the development of DMIS theory was based on psychological theory, George Kelly's construct theory. The personal construct theory explains that a person's experience functions the mental categories he uses to interpret an event. This understanding can be concluded that the existence of an event depends on a person's ability to distinguish the event from other similar events (Bennett, 2017).

Different perceptions from other cultures can only be generated if someone has the right mental category to categorize each culture. The more complex the mental categories a person has, the more capable of distinguishing and feeling cultural differences (Kurnianti \& Afrilia, 2020). In other words, the quality of a person's intercultural sensitivity is determined by how complex his mental categories are concerning categorizing other cultures (Hagley, 2020).

In intercultural sensitivity, there are six stages proposed by Bennett

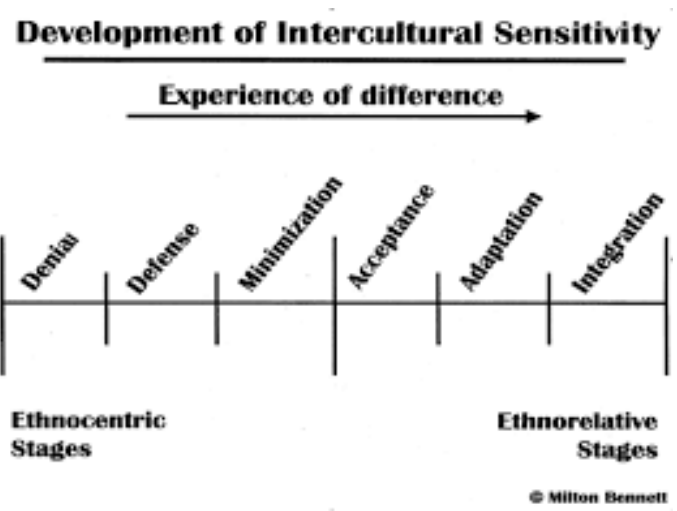

Fig 3. Intercultural Sensitibity Stages 
The first stage is the Denial Stage, where the culture attached to a person is the only culture in the world with natural patterns of beliefs, behaviors, and values. Different cultures will not be recognized for their existence. At this stage, individuals tend to isolate themselves from other groups (Barron \& Dasli, 2010). The second stage is Defense, where the culture attached to a person is the only culture. Other cultures are being labeled as a threat or lousy culture. The individual in this stage will instill that his culture is the best or the superior culture. They negatively viewed other cultures (preparing). The third stage is the minimization stage. This stage is where cultural differences are not a threatening factor. Physical universalism (equality in terms of physicality) and transcendent universalism (equality in terms of religion, economy, philosophy) were found in this stage. At this stage, it is also viewed that similarities between cultures can be created with one another. At the minimization stage, individuals begin to find similarities between themselves and individuals from different cultures. They realize that humans are still humans even though they have different traditions and cultures (Maftukhah, 2020).

The acceptance stage is the fourth stage of DMIS, where the culture attached to a person is one of the various possible views of other cultures on the world. So at this stage, people are more accepting and appreciating elements from other cultures. At this stage, people may accept, but that does not mean they will agree to other aspects of culture (Mellizo, 2018). Adaptation is the fifth stage which states that the perceptions made and the behavior that a person appears are following other cultural contexts. At this stage, it can be said that one person will treat the other according to the culture brought by the other person. The Integration stage is the last stage in the development of intercultural sensitivity, which explains that a person's experience is expanded to include movements in and out of different cultural views. Individuals who can reach the integration stage are called culture mediators. They help other individuals understand cultural differences and promote unity between two different cultures (Suryato, 2020).

\section{METHOD}

This research will be conducted in qualitative methods. Qualitative research is research that used to examine the object which the researcher is as a critical instrument, technique data collection is carried out by combining data, and the data analysis is combined, with an inductive approach, and emphasizes meaning rather than generalization (Prasanti, 2018).

This qualitative research is a research that is used to analyze and describe the data in the form of scientific words about intercultural sensitivity on Gojek's "GO INTERNATIONAL" YouTube video. The research tool that is being used to determine the data is content analysis. It is used to sense the means inside the video and systematically draw the communication aspects on the video.

The content analysis applied in this study helps researchers analyze the data obtained and categorize the data. Existing categories will be revised and verified along with the analysis process. The data collection procedures in this study are conducted through (1) determining the purpose of data collection as a guide for data collection so that it is not disturbed by other factors and (2) video recording data obtained, transcribed, and then analyzed (Andini, 2014).

The stages of inductive analysis by Mayring will be held as follows: (1) setting research questions; (2) determining the category definition and level of abstraction for the inductive category; (3) formulating data by considering category definitions, sorting existing categories, or formulating new categories; (4) revising the category as a form of formative reliability checking by taking into account the research questions; (5) finalizing the categorization process as a form of summative checking of reliability; (6) make the final interpretation (R. F. Marta et al., 2019).

\section{RESULTS AND DISCUSSION}

Table 1.

\begin{tabular}{|c|c|c|c|c|c|}
\hline No & $\begin{array}{r}\text { Segmentation Title } \\
\end{array}$ & Duration & Parcial & Relevant & Stages \\
\hline 1. & The introduction to Gojek Indonesia & 00:00-00:24 & Opening & $\mathrm{X}$ & $\mathrm{X}$ \\
\hline \multirow{2}{*}{2.} & Pipit experience as a driver at Gojek Indonesia & 00:25-00:34 & Bridge & $\mathrm{X}$ & $\mathrm{X}$ \\
\hline & Yani experience as a driver at Gojek Indonesia & 00:35-00:42 & & & $\mathrm{X}$ \\
\hline \multirow[t]{3}{*}{3.} & $\begin{array}{l}\text { Pipit tells the audiences the benefits of being a Gojek } \\
\text { driver }\end{array}$ & 00:43-01:05 & Scene 1 & $\mathrm{X}$ & $\mathrm{X}$ \\
\hline & $\begin{array}{l}\text { Yani tells the audiences the benefits of being a Gojek } \\
\text { driver }\end{array}$ & 01:06-01:14 & & & $\mathrm{X}$ \\
\hline & Pipit and Yani preparation for Vietnam & 01:15-01:22 & & & $\mathrm{X}$ \\
\hline \multirow[t]{2}{*}{4.} & $\begin{array}{l}\text { Five gojek drivers parting with their families at } \\
\text { terminal } 3 \text { Soekarno Hatta Airport }\end{array}$ & 01:23-01:36 & Scene 2 & $\mathrm{X}$ & $\mathrm{X}$ \\
\hline & Flight to Vietnam & $01: 37-02: 12$ & & & $\mathrm{X}$ \\
\hline
\end{tabular}




\begin{tabular}{|c|c|c|c|c|c|}
\hline \multirow[t]{3}{*}{5.} & $\begin{array}{l}\text { Five GO-JEK partners arrive at Tan Son Nhat . } \\
\text { International Airport }\end{array}$ & $02: 13-02: 16$ & \multirow[t]{3}{*}{ Scene 3} & \multirow[t]{3}{*}{$\mathrm{X}$} & $\mathrm{X}$ \\
\hline & Arriving at Fave Hotel & $02: 17-02: 24$ & & & $\mathrm{X}$ \\
\hline & Introduction to Vietnam & $02: 25-02: 30$ & & & $\mathrm{X}$ \\
\hline \multirow[t]{18}{*}{6.} & The first meeting of Gojek drivers and Goviet drivers & $02: 31-02: 48$ & \multirow[t]{8}{*}{ Climax } & \multirow[t]{18}{*}{$\sqrt{ }$} & Minimization \\
\hline & Sightseeing at Ho Chi Minh City & 02:49-03:01 & & & Minimization \\
\hline & Notre-Dame Cathedral Basilica & 03:02-03:06 & & & Adaption \\
\hline & Enjoying Vietnamese coffee & 03:07- 03:15 & & & Adaption \\
\hline & Sightseeing to Sentralsaigon post office & $03: 16-03: 17$ & & & Adaption \\
\hline & Wandering around Saigon Central Post Office & $03: 18-03: 24$ & & & Adaption \\
\hline & Picture taking infront of War Remnants Museum & $03: 25-03: 29$ & & & Adaption \\
\hline & $\begin{array}{l}\text { Pipit impressions on traveling to Vietnam and meeting } \\
\text { fellow Goviet drivers }\end{array}$ & $03: 30-03: 31$ & & & Acceptance \\
\hline & $\begin{array}{l}\text { Gojek and Goviet drivers enjoy Trung Vit Lon which is } \\
\text { a local snack and explanations from Pak Yani and Ibu } \\
\text { Pipit about the difficulty of learning Vietnamese }\end{array}$ & $03: 32-03: 44$ & \multirow[t]{10}{*}{ Climax } & & Integration \\
\hline & Enjoying Vietnam meatballs & $03: 45-04: 03$ & & & Adaption \\
\hline & $\begin{array}{l}\text { Gojek and Goviet drivers went to Phu My bridge for } \\
\text { sightseeing }\end{array}$ & 04:04-04:10 & & & $\mathrm{X}$ \\
\hline & $\begin{array}{l}\text { Gojek drivers accompany Goviet drivers to pray at the } \\
\text { shrine }\end{array}$ & $04: 11-04: 26$ & & & Adaption \\
\hline & $\begin{array}{l}\text { Mitra GO-VIET menemani mitra GO-JEK untuk } \\
\text { beribadah ke Masjid tertua yang terletak di jantung kota }\end{array}$ & $04: 27-04: 33$ & & & Adaption \\
\hline & Picture taking at Ho Chi Minh City Hall area & $04: 34-04: 40$ & & & Adaption \\
\hline & Wandering around Ho Chi Minh City Hall & $04: 41-04: 44$ & & & $\mathrm{X}$ \\
\hline & $\begin{array}{l}\text { Trolling around the city with a motor bike on the night } \\
\text { time }\end{array}$ & $04: 45-04: 50$ & & & $\mathrm{X}$ \\
\hline & $\begin{array}{l}\text { Showcasting the affections between Gojek and Goviet } \\
\text { on their trip at Vietnam }\end{array}$ & $04: 51-04: 55$ & & & Integration \\
\hline & Exchanging photos between Gojek and Goviet drivers & $04: 56-05: 00$ & & & $\mathrm{X}$ \\
\hline 7. & $\begin{array}{l}\text { Farewell between Gojek and Goviet drivers. } \\
\text { Exchanging pin and message towards one another }\end{array}$ & $05: 01-05: 29$ & Ending & $\sqrt{ }$ & Integration \\
\hline
\end{tabular}

The sequences in the video have been categorized by only selecting and focusing on the scene that shows the interaction between Gojek and Goviet drivers to emphasize the intercultural sensitivity of Gojek drivers towards Goviet drivers. Along with the interactions of the drivers, the reactions and expressions of joy and reverence for the food, culture, religion, and tourist attractions in Ho Chi Min City, Vietnam, the author will describe the intercultural sensitivity found between Gojek drivers and Goviet drivers. The Developmental dimension of Intercultural Sensitivity is divided into six stages, showing a person's reaction to cross-cultural differences, whether the individual is ethnocentrism or ethnorelativism. Ethnocentrism describes an individual who only considers that another culture other than his own culture is the most superior culture. The individual has his assessment of culture. Ethnorelativism is when a person begins to realize the existence of another culture and accepts it. A different culture is no longer considered threatening.

Advertisement is known as a promotion media and corporate message delivery to the public. It is not uncommon for us to find a specific message being underlined by the message maker. Interaction between two different cultures is clearly illustrated in the Gojek Go International ads.

The storyline begins with the introduction of Gojek drivers who have been working in Indonesian online transportation companies for a long time. The advertisement explains the improvement in the driver's living standards since joining Gojek. Five drivers who have been loyal to work at Gojek, namely Pipit Pitiasih from Jakarta, M. Yani from Jakarta, Fahri Ali from Makassar, Abdul Salam from Malang, and Hendra from Palembang, went on a flight with Gojek to Vietnam to meet their fellow Goviet partner.

The intercultural essence can be seen on Gojek driver's first encounter with the Goviet drivers at Vietnam's airport, Tan Son Nhat International Airport, located in Ho Chi Minh City. 


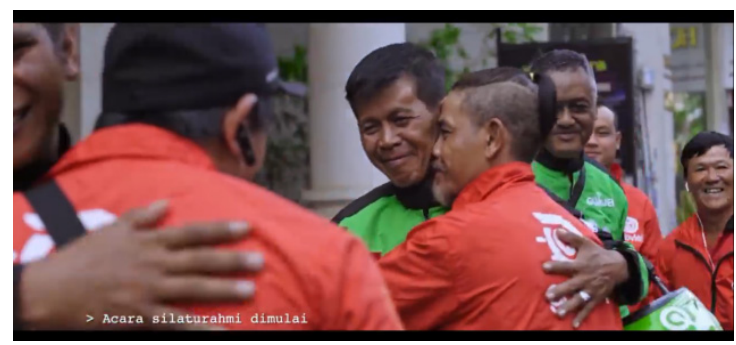

Fig 4. First Encounter between Gojek and Goviet

Starting from 02:31 to 02:48, the first meeting between Gojek drivers and Goviet drivers. The first meeting showed that both parties were trying to build intimacy and a sense of kinship as fellow Gojek partners. The female driver, Pipit, and the male driver, Yani, seemed to hug the Goviet driver and the Gojek driver also said that the Goviet driver looked similar to them. At the 17 seconds of the climax scene, the Gojek brand was also being echoed, where the Goviet driver pointed at the Gojek Logp on the Gojek driver's jacket.

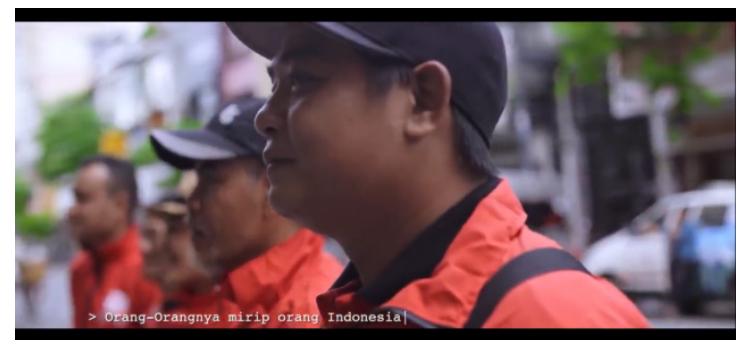

Fig 5..The Similarity between Indonesian and Vietnamese

On the $02: 31$ to $02: 48$ minutes, the intercultural sensitivity stage found in the sequences was the minimization stage, where Gojek drivers began to reduce their anxiety and negative feelings about different cultures. The moment they met Goviet drivers, they found similarities between them and the Goviet driver.

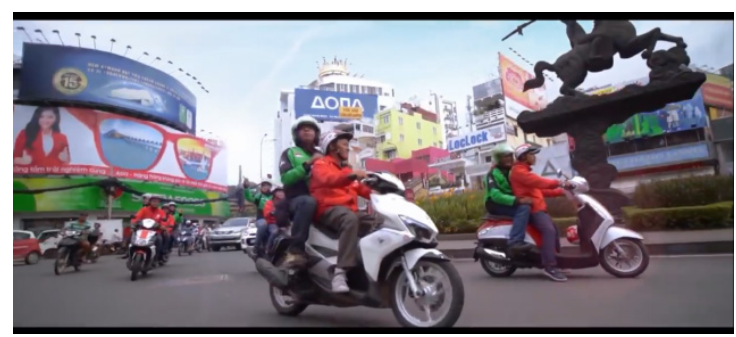

Fig 5. Gojek Drivers Ride Sharing with Goviet Drivers

Similar to the first minute of the climax scene, at 02:49 to 03:01, the minimization still radiates on Gojek drivers. Together with the Goviet drivers, Gojek drivers went sightseeing around Ho Chi Minh City. It shows the effort taken from Goviet drivers to make GO-JEK drivers familiar with their city and culture.

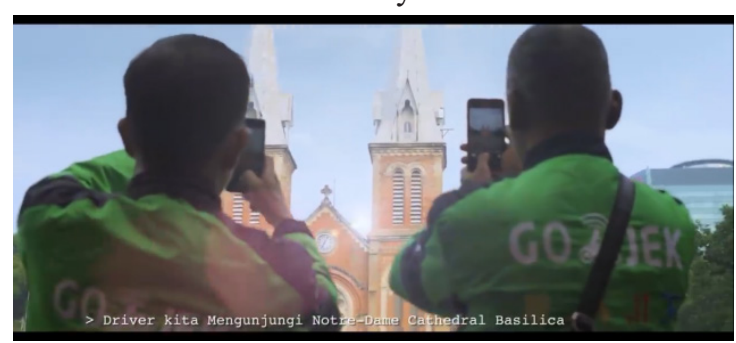

Fig 6. .Sightseeing to Notre-Dame Cathedral Basilica

As a newcomer, Gojek drivers are invited to visit tourist attractions in Ho Chi Min City. From 03:02 to 03:06, drivers visit Notre-Dame Cathedral Basilica, one of the tourist attractions in Vietnamese. In the footage, it appears that two Gojek drivers are capturing Notre-Dame Cathedral Basilica. It shows that there are exploration activities and the process of finding out more about other cultures. Adaptation is the stage that describes these activities. 


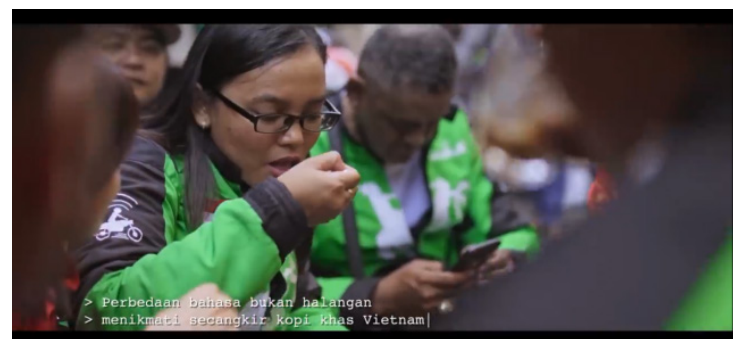

Fig 7. Gojek Drivers Enjoying Vietnames Coffee

Vietnamese coffee is one of the famous drinks in Vietnam. Drivers are invited to enjoy Vietnamese coffee on the roadside. From 03:07 to 03:15, Gojek partners seemed to be enjoying coffee while laughing and chatting with Goviet drivers. It was said in the subtitle of the snippet that "Difference is not an obstacle" despite different cultures and languages, the two Gojek partners can get along with one another.

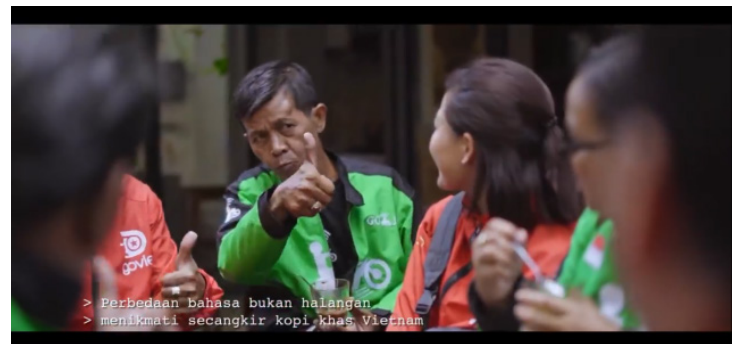

Fig 8. Gojek Drivers Enjoying Vietnamese Coffee

One of the Gojek drivers, Yani, also gave a thumbs up after tasting Vietnamese coffee, indicating the enjoyment of Vietnamese coffee, which is, of course, different from Indonesian coffee. By voluntarily, they explore the foreign culture. The journey of Gojek and Goviet continues to the next tourist spot, the Saigon Central Post Office, one of the favorite tourist attractions in Vietnam, where tourists can buy various souvenirs and learn about the history of Vietnam.

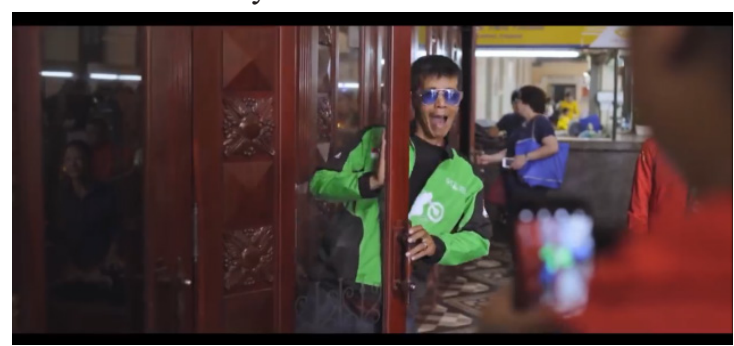

Fig 9. Sightseeing to the Sentral Saigon Post Office

From 03:16 to 03:27, showed the enthusiasm of Gojek drivers in exploring the Saigon Central Post Office. They also took memorable photographs of their series of fun experiences with the help of Goviet drivers. Adaptation is the stage where the perception made and the behavior that a person appears in follow another culture's context. It is a stage that is shown on 03:16 to 03:27 scene. Gojek drivers respect and admire all historical heritage showing that they treat Goviet driver culture well. They did not feel reluctant to explore the historical tourist spot in Ho Chi Min City. Pipit, the female Gojek driver, is also seen wearing Non-La hats, a traditional Vietnamese hat.

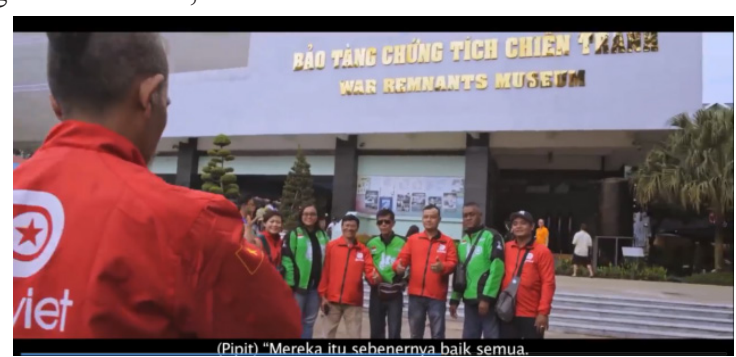

Fig 10. Taking Picture at War Remnants Museum

From 03:25 to 03:29, the drivers visit the War Remnants Museum. They seem to be taking intimate pictures together, showing the openness of Gojek drivers towards Goviet drivers (Adaptation). By acting polite and respecting 
Vietnamese culture, Gojek drivers began to study the history of the Vietnam War to open up to Vietnamese culture.

The friendliness of Goviet drivers affects the level of intercultural sensitivity of Gojek drivers (Acceptance), where Gojek drivers feel welcome in Vietnam, making them also open and appreciate Vietnamese culture. It could be seen from the interview of Pipit, Gojek driver who said, "They are all good. They are friendly with new friends. They are also welcome.." at 03:30 to 03:31 sequences.

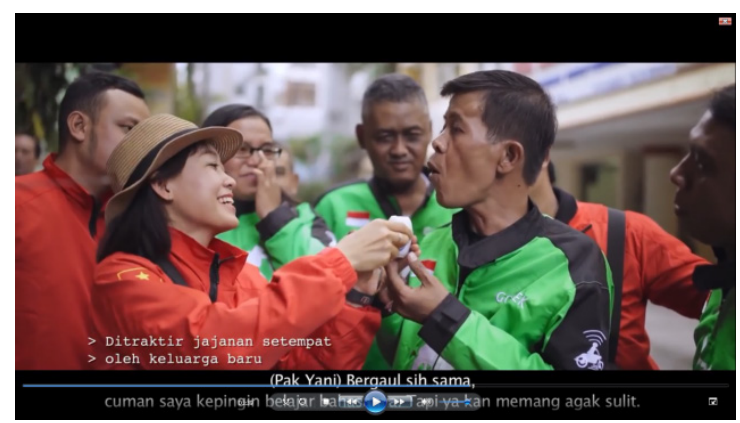

Fig 11. Gojek Drivers Trying Trung Vit Lon

From 03:32 to 03:44, Gojek drivers are asked to taste Trung Vit Lon, a local snack in Ho Chi Min City. Trung Vit Lon is an embryonic duck egg that is boiled and eaten straight from the shell. Yani, the Gojek driver, was happy to taste the snacks. Yani said that "It is not hard to get along with them. I want to learn the language. However, yeah, although it is a bit difficult."

The spirit of learning the Vietnamese language shows the emergence of empathy for Vietnamese culture. After going through various cultural experiences in Vietnam, the drivers become familiar and want to further integrate themselves with Vietnamese culture by learning the Vietnamese language so that it would be easier to understand one another.

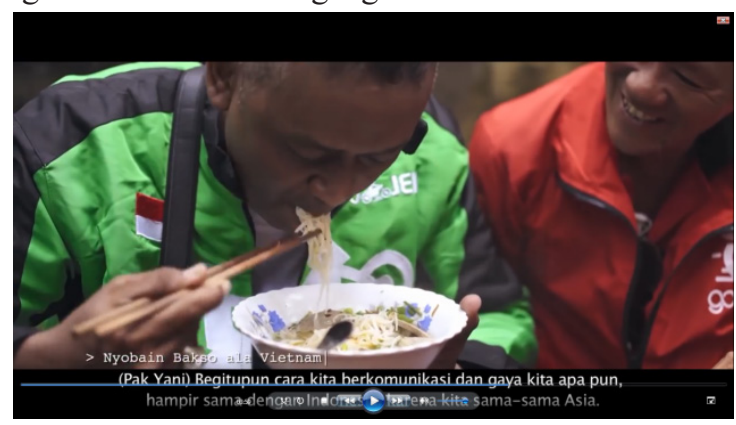

Fig 12. Enjoying Vietnamese Meat Balls

03:45 to 04:03 indicate the interactions between drivers while enjoying Vietnamese meatballs. Gojek drivers have started to adapt and are more confident in communicating with Goviet drivers. They also have started to enjoy Vietnamese culture. Politely ate Vietnamese food and endlessly tried to learn their culture.

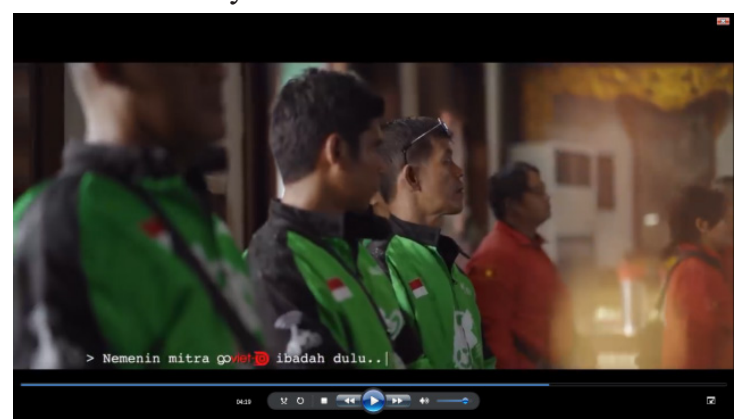

Fig 13. Gojek Drivers Accompanied Govietd Drivers to The Shrine

Goviet drivers, who are primarily Buddhist, were accompanied by Gojek drivers to pray at a shrine. Appeared at 04:11 to 04:26, Gojek drivers patiently and enthusiastically accompanied Goviet drivers to fulfill their spiritual needs. 


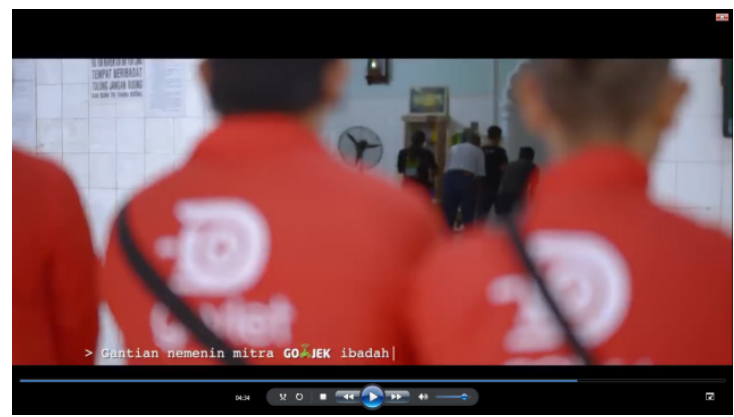

Fig 14..Goviet Drivers Accompanied Gojek Drivers to the mosque

It showed the adaptation within the Gojek drivers who remain steadfast in their values and religion and respect the Goviet drivers' religion. Further showed that Gojek drivers are interested and appreciate the culture and religion in Vietnam, but they still stick to their values. The sequences from 04:34 to 04:40 showed a group photo activity filled with laughter from Gojek and Goviet drivers in the Ho Chi Minh City Hall area. Expressions of joy and embracing each other show kinship, intimacy, and acceptance, regardless of all differences (Adaptation).

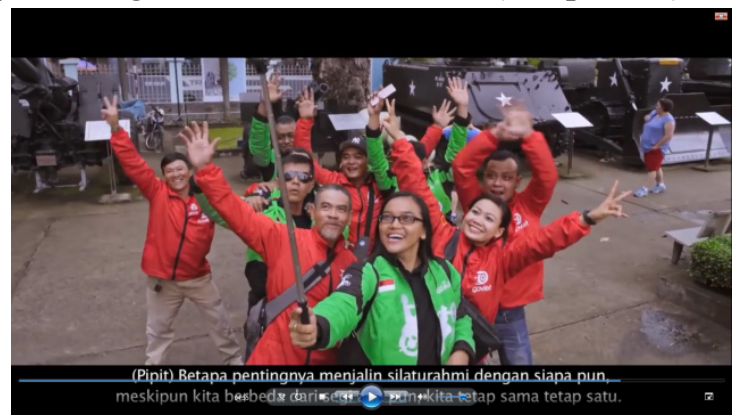

Fig 15. Capturing the Moments between Gojek and Goviet Drives

"How important it is to establish friendship with anyone, even though we are different in any way, we are still the same as one," at minute 04:51 to 04:55, the sequences featuring audio of the interview with Pipit. This Gojek driver shows that the Gojek drivers have fully understood the essence of cross-culturalism, and there has also been a feeling in them to unite into one family even though there are a series of differences between them (Integration).

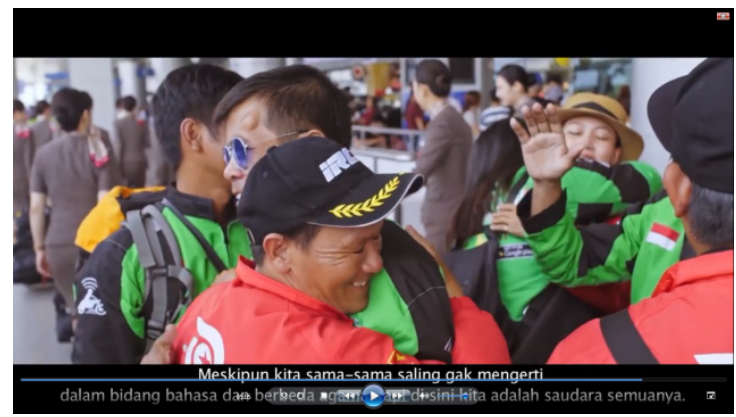

Fig 16.Farewell between Gojek and Goviet Drivers

Every new meeting will lead us to a farewell. The time has come for Gojek drivers to return to Indonesia. The Gojek and Goviet drivers were hugging one another, showing the affection and intimacy between them. Pipit, Gojek female driver's could not contain her sadness and cried while hugging the Goviet female driver. In the interview session, Pipit said, "Even though both of Gojek and Goviet drivers did not understand each other's language and has different religions, but here we are all a family." Gojek driver Yani cried and said, "Hopefully, Goviet can come to Indonesia, and I can come back here again." From 05:01 to 05:29, we can see the empathy of Gojek drivers where they consider Goviet as the new family.

\section{CONCLUSION}

Intercultural sensitivity is being used to determine individual responses to different cultures. From the results above conveyed through the content analysis method, the author finds four stages of intercultural sensitivity that the Gojek driver has and appears in the ads, such as minimization, acceptance, adaptation, and integration. At the first encounter 
between Gojek and Goviet drivers, the feelings of anxiety, fear, and suspicion could be found within the Gojek drivers. Gojek drivers seemed excited after meeting the Goviet drivers who looked visually similar and friendly, welcoming them at the airport. It refers to the minimization stage that appears at the beginning of the meeting.

The next stage is acceptance. Gojek drivers reduce their anxiety and begin to accept and appreciate different cultures. The friendliness of Goviet drivers pulls down their guar and helps them to open up. The most shown intercultural sensitivity stage that was shown in the Gojek advertisement was the adaptation stage. Cultural differences are not an obstacle for two different cultures to unite. Even though they follow and appreciate different cultures, both Gojek and Goviet drivers firmly hold onto their respective values and religions. They are also actively exploring Vietnamese culture and appreciate all existing differences.

The Gojek drivers have reached the integration stage, where they integrate themselves with the Goviet drivers, showing their empathy for each other and having an immediate sense of brotherhood. Although their intimate time was short, it was enough for them to adapt to each culture. They realize that they have an unforgettable impression in the journey and believe that they are one family despite their differences. This sense of empathy and family warmth in cultural differences will be the key to strengthening the Gojek brand in the future.

\section{REFERENCES}

[1] Allianz x GoJek. (n.d.). Retrieved August 6, 2021, from https://www.allianz.co.id/program-allianz/promo/ partnership/tenang-pakai-allianz/allianz-X-gojek.html

[2] Andini, I. (2014). Ketaksaan Tindak Tutur Dalam Wacana Humor Pada Acara Sentilan Sentilun Di Metro Tv. BAHTERA : Jurnal Pendidikan Bahasa Dan Sastra, 13(1), 11-19. https://doi.org/10.21009/bahtera.131.02

[3] Aprilyansyah, A. (2018). Upaya Indonesia Dalam Menjadikan Bahasa Indonesia Sebagai Bahasa Internasional Di Asia Tenggara. Global Political Studies Journal, 2(2), 88-100. https://doi.org/10.34010/gpsjournal.v2i2.2025

[4] Aziz, Z. (2019). Fluxus Animasi Dan Komunikasi Di Era Media Baru Digital. CHANNEL: Jurnal Komunikasi, 7(1), 49. https://doi.org/10.12928/channel.v7i1.13017

[5] Barron, P., \& Dasli, M. (2010). Towards an understanding of integration amongst hospitality and tourism students using Bennett's developmental model of intercultural sensitivity. Journal of Hospitality, Leisure, Sport and Tourism Education, 9(2), 77-88. https://doi.org/10.3794/johlste.92.311

[6] Bennett, M. J. (2017). Developmental Model of Intercultural Sensitivity. The International Encyclopedia of Intercultural Communication, June 2017, 1-10. https://doi.org/10.1002/9781118783665.ieicc0182

[7] Dağhan, G. (2017). Views of students about technology, effects of technology on daily living and their professional preferences. Turkish Online Journal of Educational Technology, 16(4), 187-194.

[8] Hagley, E. (2020). Effects of virtual exchange in the efl classroom on students' cultural and intercultural sensitivity. Computer Assisted Languaged Learning Electronic Journal, 21(3), 74-87.

[9] Heryani, H. (2020). Strategi Pengembangan Industri Kreatif untuk Inovasi. Jurnal Teknologi Industri Pertanian, 30(3), 290-298. https://doi.org/10.24961/j.tek.ind.pert.2020.30.3.290

[10] Islam, J. E., Bebas, P., \& Islam, P. E. (2017). Analisis Kebijakan Indonesia Menghadapi Tenaga Kerja Asing Dalam Pasar Bebas. AT-TAUZI': Jurnal Ekonomi Islam, 16(2), 509-522. https://jurnalhamfara.ac.id/index.php/attauzi/ article/download/26/18

[11] Junita, I. (2019). Transformational Leadership in Digital Era: Analysis of Nadiem Makarim (Founder of GO-JEK Indonesia) Leadership Figure. Integrated Journal of Business and Economics, 3(1), 80. https://doi.org/10.33019/ ijbe.v3i1.106

[12] Kartika, N. E. (2020). Fitur Aplikasi Gojek Favorit Konsumen Pada Saat Pandemi COVID-19 Di Kota Bandung. Jurnal Communio : Jurnal Jurusan Ilmu Komunikasi, 9(2), 1680-1695. https://doi.org/10.35508/jikom.v9i2.2922

[13] Kurnianti, A. W., \& Afrilia, A. M. (2020). Hubungan Intercultural Sensitivity Dengan Efektivitas Komunikasi Dalam Mencegah Bullying di SMA Taruna Nusantara Magelang. Kanal: Jurnal Ilmu Komunikasi, 8(2), 42-49. https://doi.org/10.21070/kanal.v8i2.221

[14] Maftukhah, D. (2020). the Stages of Developmental Model of Intercutural Sensitivity Depicted in the. Konferensi Ilmiah Mahasiswa UNISSULA, 64-73.

[15] Marta, R.F., Fernando, J., K. (2020). TINJAUAN PERAN KOMUNIKASI KELUARGA PADA KINERJA PUBLIC RELATIONS MELALUI KONTEN LAMAN RESMI MEDIA Family Roles Communication Review on Public Relations Activity. Jurnal Komunikasi Pembangunan, 18(01), 30-42.

[16] Marta, R.F., Robin, P. (2019). Kebahasaan Sinematik Bernuansa Pluralitas Dalam Iklan Bni Taplus Anak. Communication Journal, 10(1), 16. https://doi.org/10.36080/comm.v10i1.810 
[17] Marta, R. F., Fernando, J., \& Simanjuntak, R. F. (2019). Eksplikasi Kualitas Konten Peran Keluarga Pada Instagram @ Kemenpppa. ETTISAL : Journal of Communication, 4(2), 137. https://doi.org/10.21111/ejoc.v4i2.3702

[18] Marta, R., \& Rieuwpassa, J. S. (2018). Identifikasi Nilai Kemajemukan Indonesia Sebagai Identitas Bangsa dalam Iklan Mixagrip Versi Keragaman Budaya. Jurnal Kajian Komunikasi, 6(1), 37. https://doi.org/10.24198/jkk. v6i1.15416

[19] Mellizo, J. M. (2018). Applications of the developmental model of intercultural Sensitivity (DMIS) in music education. Music Education Praxis Journal, 2(2), 46-67.

[20] Prananda, N. I., Chan, B. Y., Lim, L. C., \& Poon, W. C. (2020). Go-Jek Company : Go-Jek's Rise to Dominating Indonesian's Markets and Southeast Asean. TEST Engineering and Management Journal, 82(April), $735-743$.

[21] Prasanti, D. (2018). Penggunaan Media Komunikasi Bagi Remaja Perempuan Dalam Pencarian Informasi Kesehatan. LONTAR: Jurnal Ilmu Komunikasi, 6(1), 13-21. https://doi.org/10.30656/lontar.v6i1.645

[22] Rahmadani, \& Fahrudin, A. (2020). Kualitas Hidu Driver Go-jek Online di Tangerang Selatan. Khidmat Sosial , Journal of Social Work and Social Service, 1(1), 27-41.

[23] Sari, R. P., \& Suprihatin, S. (2020). Akulturasi Budaya Pada Komunitas Virtual 'Sobat Ambyar.' CHANNEL: Jurnal Komunikasi, 8(1), 25. https://doi.org/10.12928/channel.v8i1.15058

[24] Sasongko, Y. P. D., \& Marta, R. F. (2018). Ekspresi Identitas Melalui Relasi Ayah Dan Anak Pada Iklan Youtube Grab Official. Bricolage : Jurnal Magister Ilmu Komunikasi, 4(02), 118. https://doi.org/10.30813/bricolage.v4i02.1656

[25] Setiadi, E. (2016). Perjanjian Ekstradisi antara Indonesia dan Vietnam. International \& Diplomacy Journal, 2(1), 83-94.

[26] Setiawan, J. H., Caroline, C., \& Muharman, D. (2021). CONTENT ANALYSIS OF READERS 'COMMENTS ON MEDIA AGGREGATOR AS FEEDBACK AND FORM OF PUBLIC OPINION ABOUT COVID-19. ASPIRATION Journal, 2(July), 45-60.

[27] Suryato. (2020). Sensitivitas antar budaya mahasiswa di Yogyakarta. Civics: Media Kajian Kewarganegaraan Journal, 17(2), 195-202. 
